\title{
Kewenangan Majelis Pengawas Notaris Dalam Pencegahan Terjadinya Pelanggaran Kewenangan Dan Tugas Jabatan Notaris
}

\author{
Ratna Madyastuti \\ Fakultas Hukum Univrsitas Islam Indonesia Yogyakarta Indonesia \\ Jln. Cik Di Tiro No. 1 Yogyakarta 55223 Indonesia \\ ratnamadyastuti0707@gmail.com
}

\begin{abstract}
This study aims to analyze the form of supervision carried out by the Notary Supervisory Council (MPN) on Notaries who carry out their positions to prevent violations of the authority of the Notary's office and to analyze differences in the authority of the Notary Supervisory Council and the Notary Honorary Council (DKN) in regards to the public reports suspected violations of Code of Ethics carried out by the Notary. This is an empirical juridical legal research, namely on the enactment or implementation of normative legal provisions on real behavior in every legal event that occurs in society. The results of the research conclude that the supervision carried out by the MPN to prevent violations of the notary's position is by holding hearings on notary, holding a meeting once a month attended by the Regional Supervisory Council (MPD) to provide directions to implement UUJN and the Code of Ethics and MPD to pay visits to the Notary's office at least once a year to check on the Notary protocol. Whereas the Notary Code of Ethics is a regulation that applies to members of the Notary's organization, if there is a violation of the Notary's Code of Ethics, the Notary's organization through $D K N$ is obliged to examine the Notary and hold a hearing on the examination of the violation.
\end{abstract}

Key Words: Notarial function; notary supervision; supervisory authority

\begin{abstract}
Abstrak
Penelitian ini bertujuan untuk menganalisis bentuk pengawasan yang dilakukan oleh Majelis Pengawas Notaris (MPN) terhadap Notaris yang menjalankan jabatannya untuk mencegah terjadinya pelanggaran kewenangan jabatan Notaris dan menganalisis perbedaan kewenangan Majelis Pengawas Notaris dengan Dewan Kehormatan Notaris (DKN) terkait pelaporan dari masyarakat atas dugaan pelanggaran kode etik yang dilakukan oleh Notaris. Penelitian ini adalah penelitian hukum yuridis empiris, yaitu penelitian hukum mengenai pemberlakuan atau implementasi ketentuan hukum normatif terhadap perilaku nyata pada setiap peristiwa hukum yang terjadi di masyarakat. Hasil penelitian menyimpulkan bahwa pengawasan yang dilakukan MPN untuk mencegah terjadinya pelanggaran jabatan Notaris yaitu dengan cara mengadakan seminar tentang kenotariatan, mengadakan pertemuan sebulan sekali yang dihadiri Majelis Pengawas Daerah (MPD) guna memberikan arahan supaya menjalankan UUJN dan Kode Etik serta MPD melakukan kunjungan ke kantor Notaris minimal setahun sekali guna melakukan pengecekan protokol Notaris. Bahwa kode etik Notaris merupakan peraturan yang berlaku untuk anggota organisasi Notaris, jika terjadi pelanggaran terhadap kode etik Notaris tersebut maka organisasi Notaris melalui DKN berkewajiban untuk memeriksa Notaris dan menyelenggarakan sidang atas pemeriksaan atas pelanggaran tersebut.
\end{abstract}

Kata-kata Kunci: Jabatan notaris; pengawasan notaris; kewenangan pengawasan 


\section{Pendahuluan}

Negara Republik Indonesia sebagai negara hukum berdasarkan Pancasila dan Undang-Undang Dasar Negara Republik Indonesia Tahun 1945 menjamin kepastian, ketertiban dan perlindungan hukum bagi setiap warga negara. Untuk menjamin kepastian, ketertiban dan perlindungan hukum dibutuhkan alat bukti tertulis yang bersifat otentik mengenai perbuatan, perjanjian, penentapan dan peristiwa hukum yang dibuat dihadapan atau oleh pejabat yang berwenang. ${ }^{1}$

Notaris berdasarkan Undang-Undang Nomor 2 Tahun 2014 tentang Perubahan Atas Undang-Undang Nomor 30 Tahun 2004 tentang Jabatan Notaris (UUJN) adalah pejabat umum yang berwenang untuk membuat akta otentik dan memiliki kewenangan lainnya sebagaimana dimaksud dalam Undang-Undang ini atau berdasarkan Undang-Undang lainnya. ${ }^{2}$ Terhadap pasal tersebut di atas dapat dipahami bahwa Notaris adalah pejabat umum yang secara khusus diberikan wewenang oleh Undang-Undang untuk membuat suatu alat bukti yang otentik.

Kehadiran jabatan Notaris dihendaki oleh aturan hukum dengan maksud untuk membantu dan melayani masyarakat yang membutuhkan alat bukti tertulis yang bersifat otentik mengenai keadaan, peristiwa atau perbuatan hukum. ${ }^{3}$ Atas dasar tersebut, mereka yang diangkat sebagai Notaris harus mempunyai semangat untuk melayani masyarakat dan atas pelayanan tersebut masyarakat yang telah dilayani oleh Notaris sesuai dengan kewenangan dan tugas jabatannya, memberikan honorarium kepada Notaris. Karenanya, Notaris tidak berarti apa-apa jika masyarakat tidak membutuhkannya. ${ }^{4}$

Pada 1860 Pemerintah Hindia Belanda memandang perlu untuk membuat peraturan-peraturan yang mengatur mengenai jabatan Notaris di Nederlands Indie untuk disesuaikan dengan peraturan-peraturan mengenai jabatan Notaris yang berlaku di Belanda. Keberadaannya di nusantara sejak zaman kolonial Belanda mendasarkan pada Reglement op Het Notaris Ambt in Indonesie (Stb. 1860 No.3). ${ }^{5}$ Kehadiran Notaris memegang peranan penting dalam lalu lintas hukum, khususnya yang berkaitan dengan pembuatan alat bukti tertulis yang bersifat

${ }^{1}$ Muhammad Luthfan Hadi Darus, Hukum Notariat dan Tanggungjawab Jabatan Notaris, Cetakan Pertama UII Press, Yogyakarta 2017, hlm. 1.

2 Lihat di dalam Pasal 1 angka 1 Undang-Undang Nomor 2 Tahun 2014 tentang Perubahan Atas Undang-Undang Nomor 30 Tahun 2004 tentang Jabatan Notaris.

3 Secara substantif akta Notaris dapat berupa: (1) suatu keadaan, peristiwa, atau perbuatan hukum yang dikehendaki oleh para pihak agar dituangkan dalam bentuk akta otentik untuk dijadikan sebagai alat bukti; (2) berdasarkan peraturan perundang-undangan bahwa tindakan hukum tertentu wajib dibuat dalam bentuk akta otentik.

4 Herlien Budiono, "Notaris dan Kode Etiknya", Disampaikan pada Upgrading dan Refreshing Course Nasional Ikatan Notaris Indonesia, Ikatan Notaris Indonesia, Medan, 2007, hlm. 3.

${ }^{5}$ Stb. 1860 No. 3 diundangkan untuk menggantikan aturan sebelumnya yakni Stb. No. 11. 
otentik. Diamanatkan dalam Pasal 1868 Kitab Undang-Undang Hukum Perdata yang berbunyi akta otentik adalah akta yang dalam bentuk yang ditentukan oleh undang-undang dibuat oleh atau di hadapan pejabat umum yang berwenang untuk itu di tempat dimana akta itu dibuat. ${ }^{6}$

Akta otentik yang dibuat oleh Notaris ada 2 macam yaitu: ambtelijk acte dan party acte. Ambtelijk acte yaitu akta yang dibuat oleh Notaris yang berdasarkan pengamatan yang dilakukan oleh Notaris tersebut. Akta jenis ini diantaranya adalah akta berita acara Rapat Umum Pemegang Saham (RUPS) perseroan terbatas, akta pendaftaran atau inventarisasi harta peninggalan. Selain itu, definisi dari party acte atau akta para pihak adalah akta yang dibuat oleh dan di hadapan Notaris berdasarkan kehendak atau keinginan para pihak dalam kaitannya dengan perbuatan hukum yang dilakukan oleh para pihak. Contoh akta ini di antaranya adalah akta sewa menyewa dan akta perjanjian kredit.

Notaris sebagai pejabat publik yang berwenang dalam membuat akta otentik memiliki peranan penting dalam kehidupan masyarakat sehingga Notaris sebagai pejabat umum pembuat akta otentik dituntut memiliki kepribadian yang baik, bekerja keras, mandiri, jujur, tidak memihak (adil) dan penuh rasa tanggungjawab. Notaris juga dituntut juga memiliki kecakapan atau penguasaan dalam bidang hukum yang menjadi kompetensinya. Tuntutan akan kecakapan dalam memberikan jasa dalam bidang hukum keperdataan ini Notaris juga dituntut untuk memberikan penyuluhan hukum (legal advicer) kepada kliennya agar terhindar dari kesesatan hukum dan mengetahui hak dan kewajibannya.

Notaris mempunyai kewajiban dalam menjalankan tugas jabatannya yang diatur dalam ketentuan Pasal 16 UUJN, yang menyebutkan:

Dalam menjalankan jabatannya, Notaris wajib:

a. bertindak amanah, jujur, saksama, mandiri, tidak berpihak, dan menjaga kepentingan pihak yang terkait dalam perbuatan hukum;

b. membuat Akta dalam bentuk Minuta Akta dan menyimpannya sebagai bagian dari protokol Notaris;

c. melekatkan surat dan dokumen serta sidik jari penghadap pada Minuta Akta;

d. mengeluarkan Grosse Akta, Salinan Akta, atau Kutipan Akta berdasarkan Minuta Akta.

e. memberikan pelayanan sesuai dengan ketentuan dalam Undang-Undang ini, kecuali ada alasan untuk menolaknya; merahasiakan segala sesuatu mengenai Akta yang dibuatnya dan segala keterangan yang diperoleh

${ }^{6}$ R. Subekti dan R. Tjitrosudibio, Kitab Undang-Undang Hukum Perdata, PT. Pradnya Paramita, Jakarta, 2009, hlm. 475. 
guna pembuatan Akta sesuai dengan sumpah/janji jabatan, kecuali undang-undang menentukan lain;

f. menjilid Akta yang dibuatnya dalam 1 (satu) bulan menjadi buku yang memuat tidak lebih dari 50 (lima puluh) Akta, dan jika jumlah Akta tidak dapat dimuat dalam satu buku, Akta tersebut dapat dijilid menjadi lebih dari satu buku, dan mencatat jumlah Minuta Akta, bulan, dan tahun pembuatannya pada sampul setiap buku;

g. membuat daftar dari Akta protes terhadap tidak dibayar atau tidak diterimanya surat berharga;

h. membuat daftar Akta yang berkenaan dengan wasiat menurut urutan waktu pembuatan Akta setiap bulan;

i. mengirimkan daftar Akta sebagaimana dimaksud dalam huruf i atau daftar nihil yang berkenaan dengan wasiat ke pusat daftar wasiat pada kementerian yang menyelenggarakan urusan pemerintahan di bidang hukum dalam waktu 5 (lima) hari pada minggu pertama setiap bulan berikutnya;

j. mencatat dalam repertorium tanggal pengiriman daftar wasiat pada setiap akhir bulan;

k. mempunyai cap atau stempel yang memuat lambang negara Republik Indonesia dan pada ruang yang melingkarinya dituliskan nama, jabatan, dan tempat kedudukan yang bersangkutan;

1. membacakan Akta di hadapan penghadap dengan dihadiri oleh paling sedikit 2 (dua) orang saksi, atau 4 (empat) orang saksi khusus untuk pembuatan Akta wasiat di bawah tangan, dan ditandatangani pada saat itu juga oleh penghadap, saksi, dan Notaris;

m.menerima magang calon Notaris.

Di dalam profesi dunia Notaris di Indonesia terdapat organisasi perkumpulan Notaris yang disebut Ikatan Notaris Indonesia yang selanjutnya disebut INI. Adapun tujuan dari INI selaku perkumpulan bagi Notaris-Notaris di Indonesia adalah tegaknya kebenaran dan keadilan serta terpeliharanya keluhuran martabat jabatan Notaris sebagai pejabat umum yang bermutu dalam rangka pengabdiannya kepada Tuhan Yang Maha Esa, Bangsa dan Negara agar terwujudnya kepastian hukum dan terbinanya persatuan dan kesatuan serta kesejahteraan anggotanya. ${ }^{7}$ Salah satu langkah ditegakkannya keluhuran martabat jabatan Notaris yang dilakukan organisasi INI adalah dengan membuat kode etik bagi para anggotanya.

Kode Etik Notaris merupakan seluruh kaidah moral yang menjadi pedoman dalam menjalankan jabatan Notaris. Ruang lingkup Kode Etik Notaris berlaku bagi seluruh anggota perkumpulan maupun orang lain yang memangku dan menjalankan jabatan Notaris baik dalam pelaksanaan jabatan. Organisasi INI 
berperan penting dalam penegakan etika dari para anggotanya yakni ketika ada anggota yang melanggar ketentuan yang ada di dalam kode etik profesi Notaris. Bagian dalam organisasi yang mengemban tugas dimaksud adalah Dewan Kehormatan Notaris yang terdiri dari beberapa orang anggota yang dipilih dari anggota biasa Ikatan Notaris Indonesia.

Sangat penting bagi seseorang yang mengemban tugas jabatan sebagai Notaris untuk selalu mematuhi dan melaksanakan setiap amanah yang tertuang baik di dalam ketentuan UUJN maupun kode etik jabatan Notaris itu sendiri. Notaris wajib memiliki kesadaran akan pentingnya keberadaan kode etik jabatan demi untuk kemaslahatan setiap anggota perkumpulan.

Seorang Notaris dalam menjalankan tugas jabatannya apabila terbukti melakukan pelanggaran jabatan atau etika maka dapat dikenai atau dijatuhi sanksi. Pertama, dalam penjatuhan sanksi atas pelanggaran UUJN dilakukan oleh Majelis Pengawas Notaris yang selanjutnya disebut (MPN) sebagaimana yang diatur dalam Pasal 73 ayat (1) huruf e UUJN bahwa, Majelis Pengawas Wilayah berwenang untuk memberikan sanksi berupa teguran lisan atau tertulis.

Sedangkan Notaris yang diduga melakukan pelanggaran Kode Etik Notaris atau pelanggaran UUJN maka yang berwenang melakukan pengawasan adalah Majelis Pengawas Daerah yang selanjutnya disebut (MPD) sebagaimana diatur dalam Pasal 13 ayat (2) huruf d Peraturan Menteri Hukum dan Hak Asasi Manusia Republik Indonesia Nomor: M.02.PR.08.10 Tahun 2004 tentang Tata Cara Pengangkatan Anggota, Pemberhentian Anggota Susunan Organisasi, Tata Cara Kerja dan Tata Cata Pemeriksaan Majelis Pengawas Notaris bahwa, menerima laporan dari masyarakat mengenai adanya dugaan pelanggaran Kode Etik Notaris atau pelanggaran ketentuan dalam undang-undang.

Melihat penjabaran tugas dari MPN tersebut di atas, belum tertulis secara jelas apakah ada upaya preventif yang dilakukan oleh MPN untuk mencegah adanya pelanggaran jabatan yang dilakukan oleh Notaris.

Kedua, dalam penjatuhan sanksi atas pelanggaran kode etik yang dilakukan oleh Notaris, Dewan Kehormatan Notaris yang selanjutnya disebut dengan DKN sebagaimana yang diatur dalam Pasal 8 Kode Etik Ikatan Notaris Indonesia bahwa, Dewan Kehormatan merupakan alat perlengkapan Perkumpulan yang berwenang melakukan pemeriksaan atas pelanggaran terhadap kode etik dan menjatuhkan sanksi kepada pelanggarnya sesuai dengan kewenangan masing-masing.

Apabila dicermati lebih lanjut, terdapat tumpang tindih penugasan yang menjadi kewenangan dari MPN dan DKN, yakni belum adanya pengaturan yang jelas tentang upaya preventif yang dilakukan oleh MPN untuk mencegah 
pelanggaran jabatan oleh Notaris dan adanya tumpang tindih kewenangan antara MPN dan DKN sebagaimana diuraikan di atas. Oleh karena itu penulis tertarik untuk mengkaji kedua permasalahan tersebut dengan judul penelitian Kewenangan Mejelis Pengawas Notaris Dalam Pencegahan Terjadinya Pelanggaran Kewenangan Dan Tugas Jabatan Notaris.

\section{Rumusan Masalah}

Berdasarkan uraian dalam latar belakang di atas, selanjutnya dapat dirumuskan permasalahan sebagai berikut: pertama, bagaimana bentuk pelaksanaan pengawasan yang dilakukan oleh Majelis Pengawas Notaris terhadap Notaris yang menjalankan jabatannya untuk mencegah terjadinya pelanggaran kewenangan jabatan Notaris? Kedua, bagaimana perbedaan kewenangan Majelis Pengawas Notaris dengan Dewan Kehormatan Notaris terkait pelaporan dari masyarakat atas dugaan pelanggaran kode etik yang dilakukan oleh Notaris?

\section{Tujuan Penelitian}

Bertitik tolak dari rumusan masalah di atas, maka tujuan dari penelitian ini secara umum adalah untuk: pertama, menganalisis bentuk pelaksanaan pengawasan yang dilakukan oleh Majelis Pengawas Notaris terhadap Notaris yang menjalankan jabatannya untuk mencegah terjadinya pelanggaran kewenangan jabatan Notaris; kedua, menganalisis perbedaan kewenangan Majelis Pengawas Notaris dengan Dewan Kehormatan Notaris terkait pelaporan dari masyarakat atas dugaan pelanggaran kode etik yang dilakukan oleh Notaris.

\section{Metode Penelitian}

Penelitian ini didasarkan pada penelitian kepustakaan tetapi untuk melengkapi data yang diperoleh dari penelitian kepustakaan, dilakukan juga penelitian lapangan. Oleh karena itu penelitian ini menggunakan dua jenis penelitian hukum, yaitu penelitian kepustakaan dan penelitian lapangan. Penelitian kepustakaan untuk memeroleh data sekunder dan penelitian lapangan untuk memeroleh data primer. ${ }^{8}$

Metode pendekatan yang digunakan dalam membahas masalah penelitian ini adalah pendekatan perundang-undangan (statute approach) dan pendekatan analitik (analytical approach). Pendekatan tersebut dilakukan dengan menelaah semua undang-undang dan regulasi yang bersangkut paut dengan isu hukum

8Peter Mahmud Marzuki, Penelitian Hukum, Cetakan Keduabelas, Prenadamedia Group, Jakarta, 2016, hlm. 133. 
yang sedang diteliti, dan pendekatan analitik dilakukan untuk mengetahui makna yang terkandung oleh istilah-istilah yang digunakan dalam aturan perundang-undangan secara konsepsional, sekaligus untuk mengetahui penerapannya dalam praktik dan putusan-putusan hukum sehingga dilakukan melalui dua pemeriksaan. ${ }^{9}$

\section{Hasil Penelitian dan Pembahasan}

Pelaksanaan Pengawasan yang Dilakukan oleh Majelis Pengawas Notaris Terhadap Notaris yang Menjalankan Jabatannya untuk Mencegah Terjadinya Pelanggaran Kewenangan Jabatan Notaris

Notaris dalam menjalankan tugas dan jabatannya diwajibkan untuk tunduk dan taat terhadap segala aturan yang dituangkan dalam UUJN, Kode Etik Ikatan Notaris Indonesia beserta undang-undang lainnya yang berkaitan dengan tugas jabatan Notaris. Pengawasan terhadap Notaris dilakukan oleh Majelis Pengawas Notaris secara berjenjang. ${ }^{10}$ Majelis Pengawas Notaris ini merupakan perpanjangan tangan dari Menteri Hukum dan Hak Asasi Manusia Republik Indonesia.

Tujuan dari pengawasan ini adalah agar para Notaris ketika menjalankan tugas jabatannya memenuhi persyaratan yang berkaitan dengan pelaksanaan tugas jabatan Notaris demi untuk pengamanan kepentingan masyarakat, karena Notaris diangkat oleh pemerintah bukan untuk kepentingan Notaris sendiri tetapi untuk kepentingan masyarakat yang dilayaninya. ${ }^{11}$ Notaris dalam menjalankan jabatannya sebagai pejabat umum yang berwenang membuat akta otentik diawasi oleh Majelis Pengawas Notaris yang dibentuk oleh menteri. Ketentuan mengenai pengawasan terhadap Notaris diatur dalam UUJN Bab IX tentang Pengawasan. Pengawasan secara umum dipahami sebagai kegiatan yang dilakukan oleh pengawas dalam melihat, memperhatikan, mengamati, mengontrol, menilik dan menjaga serta memberi pengarahan yang bijak.

Berdasarkan Peraturan Menteri Hukum dan Hak Asasi Manusia Republik Indonesia Nomor: M.02.PR.08.10 Tahun 2004 tentang Tata Cara Pengangkatan Anggota, Pemberhentian Anggota Susunan Organisasi, Tata Cara Kerja dan Tata Cata Pemeriksaan Majelis Pengawas Notaris Pasal 1 angka 5 mendefinisikan

'Johnny Ibrahim, Teori dan Metodologi Penelitian Hukum Normatif, Cetakan Keempat, Banyumedia, Jakarta, 2008, hlm. 321.

${ }^{10}$ Berjenjang dalam hal ini adalah berdasrkan ketentuan Pasal 68 UUJN, Majelis Pengawas Notaris terdiri dari Majelis Pengawas Daerah yang dibentuk di tingkat Kabupaten/Kota, Majelis Pengawas Wilayah yang dibentuk di tingkat Propinsi; dan Majelis Pengawas Pusat yang dibentuk di Ibukota Negara.

${ }^{11}$ G.H.S. Lumban Tobing, Peraturan Jabatan Notaris, Erlangga, Jakarta, 1983, hlm. 301. 
pengertian dari pengawasan yang berbunyi, Pengawasan adalah kegiatan yang bersifat preventif dan kuratif termasuk kegiatan pembinaan yang dilakukan oleh Majelis Pengawas terhadap Notaris. 12

Pada dasarnya yang mempunyai wewenang ${ }^{13}$ melakukan pengawasan dan pemeriksaan terhadap Notaris adalah Menteri Hukum dan Hak Asasi Manusia Republik Indonesia yang dalam pelaksanaannya Menteri membentuk Majelis Pengawas Notaris. Menteri Hukum dan Hak Asasi Manusia mempunyai tugas membantu presiden dalam menyelenggarakan sebagian urusan pemerintah di bidang hukum dan hak asasi manusia. Dengan demikian, kewenangan pengawasan terhadap Notaris ada pada pemerintah, sehingga berkaitan dengan cara pemerintah memeroleh wewenang pengawasan tersebut.

Wewenang pengawasan atas Notaris ada di tangan Menteri Hukum dan Hak Asasi Manusia. Tetapi dalam praktik, menteri melimpahkan wewenang itu kepada Majelis Pengawas Notaris yang dibentuknya. UUJN menegaskan bahwa menteri melakukan pengawasan terhadap Notaris dan kewenangan menteri untuk melakukan pengawasan ini oleh UUJN diberikan dalam bentuk pendelegasian delegatif kepada menteri untuk membentuk Majelis Pengawas Notaris, bukan untuk menjalankan fungsi-fungsi Majelis Pengawas Notaris yang telah ditetapkan secara eksplisit menjadi kewenangan Majelis Pengawas Notaris.

Dyah Maryulina Budi Mumpuni selaku anggota Majelis Pengawas Daerah Kota Yogyakarta menjelaskan, bahwa tujuan pengawasan preventif yang dilakukan Majelis Pengawas Notaris dalam melaksanakan tugas pengawasan terhadap Notaris dalam menjalankan jabatanya yakni untuk mencegah terjadinya pelanggaran kewenangan yang dilakukan Notaris. Adapun bentuk-bentuk pelaksanaannya yakni, pertama, mengadakan seminar tentang kenotariatan untuk menambah ilmu pengetahuan dan memberikan informasi tentang dunia Notaris dan mengadakan pertemuan bersama sebulan sekali yang dihadiri oleh Majelis Pengawas Daerah yang bertujuan untuk memberikan arahan supaya Notaris itu menjalankan UUJN dan Kode Etik Notaris, serta Majelis Pengawas Daerah

${ }^{12}$ Lihat di dalam Pasal 1 angka 5 Permenkumham Nomor M.02.PR.08.10 Tahun 2004 tentang Tata Cara Pengangkatan Anggota, Pemberhentian Anggota, Susunan Organisasi, Tata Kerja, dan Tata Cara Pemeriksaan Majelis Pengawas.

${ }_{13}$ Pernyataan ini mengadopsi pendapat Philipus M. Hadjon, bahwa istilah wewenang atau kewenangan yang disejajarkan dengan istilah bevoegdheid dalam konsep hukum publik. Sebagai suatu konsep hukum publik, wewenang atas (sekurang-kurangnya) tiga komponen, yaitu (1) pengaruh, bahwa penggunaan wewenang dimaksudkan untuk mengendalikan perilaku subjek hukum; (2) dasar hukum, bahwa wewenang itu selalu harus dapat ditunjuk dasar hukumnya; dan (3) konformitas hukum, bahwa mengandung makna adanya standar wewenang, yaitu standar umum (semua jenis wewenang), dan standar khusus (untuk jenis tertentu). Philipus M. Hadjon, "Tentang Wewenang Pemerintahan (Bestuursbevoegdheid)", Pro Justicia, Fakultas Hukum Universitas Parahyangan Bandung, Tahun XVI Nomor 1, Januari 1998, hlm. 2. 
melakukan kunjungan ke kantor Notaris untuk melakukan pengecekan penulisan protokol Notaris dalam jangka waktu minimal setahun sekali. ${ }^{14}$

Kedua, Majelis Pengawas Notaris juga melakukan sosialisasi kepada Notaris, masyarakat, dan kepolisian serta akademisi. Sosialisasi ini bertujuan agar pihakpihak tersebut mengetahui dan memahami adanya keberadaan institusi pengawas Notaris. Tujuan dari sosialisasi bagi masyarakat adalah agar masyarakat mengetahui hak dan kewajiban Notaris. Jika suatu saat masyarakat dirugikan oleh Notaris maka dapat melaporkan ke Majelis Pengawas Notaris selaku institusi yang berwenang melakukan pemeriksaan dan menerima aduan. Notaris Diah Maryulina Budi Mumpuni juga menjelaskan bahwa pengawasan Notaris itu dilakukan sebagai rasa tanggungjawab moral yang diberikan Majelis Pengawas Notaris kepada masyarakat walaupun di dalam undang-undang tidak menyebutkan bagaimana bentuk ataupun cara pengawasan preventif yang dilakukan Majelis Pengawas Notaris. ${ }^{15}$

Pendapat lain juga dikemukakan oleh Rio Kustianto Wironegoro, selaku Notaris yang berpraktik di Kota Yogyakarta yang mengatakan bahwa pengawasan dan pembinaan itu bagaikan dua sisi mata logam karena pengawasan itu berhubungan erat dengan pembinaan. Bahwa pengawasan itu hanya sebatas mengawasi benar tidaknya Notaris itu dalam menjalankan jabatanya dan apabila Notaris itu diduga atau terbukti tidak menjalankan jabatanya secara baik dan benar maka baru diberikan pembinaan berupa penjatuhan saksi sebagaimana diatur dalam Pasal 6 Kode Etik Notaris yaitu teguran, peringatan, schorzing (pemecatan sementara) dari anggota perkumpulan, onzetting (pemecatan) dari anggota perkumpulan, serta pemberhentian secara tidak hormat dari anggota perkumpulan. ${ }^{16}$

Penjatuhan sanksi juga disesuaikan dengan berat ringannya pelanggaran. Jika seorang Notaris melakukan pelanggaran baik kode etik maupun UUJN yang tidak merugikan masyarakat secara materi maka Notaris diberikan peringatan dan dilakukan pembinaan terlebih dahulu. Dewan Kehormatan Notaris ataupun Majelis Pengawas Notaris memberitahu bahwa Notaris yang bersangkutan telah melakukan pelanggaran yang diatur dalam peraturan perundang-undangan maupun kode etik dan diberikan penjelasan serta solusi yang tepat supaya tidak melakukan pelanggaran di kemudian hari.

\footnotetext{
${ }^{14}$ Hasil wawancara dengan Dyah Maryulina Budi Mumpuni, Notaris/PPAT Kota Yogyakarta dan Anggota Majelis Pengawas Notaris Kota Yogyakarta, tanggal 26 September 2020.

${ }^{15}$ Ibid.

${ }^{16}$ Hasil wawancara dengan Rio Kustianto Wironegoro, Notaris/PPAT Kota Yogyakarta dan juga merupakan akademisi, tanggal 26 September 2006.
} 
Bentuk pengawasan preventif yang dilakukan Majelis Pengawas Notaris untuk mencegah terjadinya pelanggaran kode etik dilakukan dengan cara refleksi jabatan Kode Etik Notaris guna memberikan materi terkait pelaksanaan jabatan Notaris, mengadakan seminar, serta Majelis Pengawas datang ke kantor Notaris minimal sebulan sekali untuk melakukan pengecekan protokol Notaris. Notaris Rio juga mengatakan bahwa bentuk pengawasan preventif yang dilakukan bersifat pasif yang artinya pengawasan itu dilakukan berdasarkan laporanlaporan dari masyarakat yang disertai dengan berbagai bukti. ${ }^{17}$

Nurhadi Darussalam selaku anggota Dewan Kehormatan Notaris periode 2001-2019 menyebutkan, bahwa pengawasan preventif yang dilakukan Majelis Pengawas Notaris untuk mencegah terjadinya pelanggaran kode etik itu hanya dengan meningkatkan ilmu pengetahuan tentang kenotariatan, mengadakan seminar, mengunjungi kantor Notaris paling sedikit setahun sekali guna mengecek protokol yang dilakukan oleh MPD, mengadakan pertemuan bersama sebulan sekali guna menselaraskan kinerja jabatan Notaris. ${ }^{18}$ Tujuan dari pengawasan yang dilakukan terhadap Notaris adalah supaya Notaris sebanyak mungkin memenuhi persyaratan-persyaratan yang dituntut kepadanya. Persyaratan-persyaratan yang dituntut itu tidak hanya oleh hukum atau undangundang saja, akan tetapi juga berdasarkan kepercayaan yang diberikan oleh klien terhadap Notaris tersebut. Tujuan dari pengawasan itupun tidak hanya ditujukan bagi penataan Kode Etik Notaris akan tetapi juga untuk tujuan yang lebih luas, yaitu agar para Notaris dalam menjalankan tugas jabatannya memenuhi persyaratan-persyaratan yang ditetapkan oleh undang-undang demi pengamanan atas kepentingan masyarakat yang dilayani. ${ }^{19}$

Adapun tahapan-tahapan atau proses pemanggilan Notaris yang diduga melakukan pelanggaran tugas jabatan dapat mengacu pada ketentuan Pasal 22 Peraturan Menteri Hukum dan Hak Asasi Manusia Republik Indonesia Nomor M.02.PR.08.10 Tahun 2004 tentang Tata Cara Pengangkatan Anggota, Pemberhentian Anggota, Susunan Organisasi, Tata Kerja, dan Tata Cara Pemeriksaan Majelis Pengawas ialah sebagai berikut:20

(1) Ketua Majelis Pemeriksa melakukan pemanggilan terhadap pelapor dan terlapor.

${ }^{17}$ Ibid.

${ }^{18}$ Hasil wawancara dengan Nurhadi Darussalam, Werda Notaris, Akademisi, serta Anggota Dewan Kehormatan Wilayah Kota Yogyakarta Tahun 2001-2019, tanggal 28 September 2020.

${ }^{19}$ Lihat di dalam Pasal 67 Ayat (1) huruf a Undang-Undang Nomor 30 Tahun 2004 tentang Perubahan Atas Undang-Undang Nomor 2 Tahun 2014 tentang Jabatan Notaris.

${ }^{20}$ Lihat di dalam Pasal 22 Peraturan Menteri Hukum dan HAM Republik Indonesia Nomor M.02.PR.08.10 Tahun 2004 tentang Tata Cara Pengangkatan Anggota, Pemberhentian Anggota, Susunan Organisasi, Tata Kerja, dan Tata Cara Pemeriksaan Majelis Pengawas. 
(2) Pemanggilan dilakukan dengan surat oleh sekretaris dalam waktu paling lambat 5 (lima) hari kerja sebelum sidang.

(3) Dalam keadaan mendesak pemanggilan sebagaimana dimaksud pada ayat (2) dapat dilakukan melalui faksimili yang segera disusul dengan surat pemanggilan.

(4) Dalam hal terlapor setelah dipanggil secara sah dan patut, tetapi tidak hadir maka dilakukan pemanggilan kedua.

(5) Dalam hal terlapor setelah dipanggil secara sah dan patut yang kedua kali namun tetap tidak hadir maka pemeriksaan dilakukan dan putusan diucapkan tanpa kehadiran terlapor.

(6) Dalam hal pelapor setelah dipanggil secara sah dan patut tidak hadir, maka dilakukan pemanggilan yang kedua, dan apabila pelapor tetap tidak hadir maka Majelis Pemeriksa menyatakan laporan gugur dan tidak dapat diajukan lagi.

Berdasarkan uraian di atas, maka dapat dicermati bahwa ada beberapa cara pengawasan yang dilakukan Majelis Pengawas Notaris untuk mencegah terjadinya pelanggaran jabatan Notaris. Antara lain mengadakan seminar tentang kenotariatan, mengadakan pertemuan sebulan sekali yang dihadiri Majelis Pengawas Daerah guna memberikan arahan supaya menjalankan UUJN dan Kode Etik serta Notaris dituntut untuk tetap menambah wawasan tentang kenotariatan. Majelis Pengawas Daerah juga melakukan kunjungan ke kantor Notaris minimal setahun sekali guna melakukan pengecekan protokol Notaris.

Pengawasan yang dapat dilakukan Majelis Pengawas Notaris untuk mencegah terjadinya pelanggaran jabatan Notaris hanyalah pengawasan yang bersifat pasif. Pengawasannya hanya menunggu laporan dari masyarakat tidak mengawasi satu persatu Notaris. Notaris yang diduga atau terbukti melakukan pelanggaran jabatan baru diberikan pembinaan berupa penjatuhan sanksi, namun penjatuhan sanksi juga disesuaikan dengan berat ringannya pelanggaran. Apabila Notaris melakukan pelanggaran yang bersifat ringan maka Dewan Kehormatan Notaris atau Majelis Pengawas Notaris baru memberikan teguran dan memberikan solusi atau arahan supaya Notaris tersebut tidak melakukan pelanggaran di kemudian hari.

\section{Perbedaan Kewenangan Majelis Pengawas Notaris dengan Dewan Kehormatan Notaris Terkait Pelaporan dari Masyarakat Atas Dugaan Pelanggaran Kode Etik yang Dilakukan Notaris}

Jabatan Notaris merupakan jabatan kepercayaan, maka dari itu seorang Notaris harus mempunyai perilaku baik yang dijamin oleh undang-undang maupun organisasi Notaris. Perilaku Notaris yang baik adalah yang berlandaskan pada UUJN dan Kode Etik Notaris. Dengan demikian Kode Etik Notaris 
mengatur hal-hal yang harus ditaati oleh seorang Notaris dalam menjalankan jabatannya dan juga di luar jabatannya.

Notaris juga dianggap sebagai insan yang memiliki kemampuan di bidangnya (profesional). Dengan demikian profesional dalam suatu jabatan diartikan sebagai orang yang memegang jabatan atau memiliki pekerjaan yang dilakukan atas dasar kemampuan yang tinggi dan berpegang teguh kepada nilai moral yang mengarahkan dan mendasari perbuatan, atau orang yang hidup dengan cara mempraktikkan suatu keterampilan atau keahlian tertentu dan mendapatkan imbalan besar sepadan dengan kemampuan profesionalnya (well educated, well trained, well paid).21

Pengawasan Notaris dibedakan antara perilaku dan tindakan yang dilakukan oleh Notaris dalam menjalankan jabatanya oleh Majelis Pengawas Notaris. Sedangkan perilaku dan tindakan yang dilakukan oleh Notaris diluar menjalankan jabatanya diawasi oleh Dewan Kehormatan Notaris. Pengawasan tersebut pada dasarnya adalah wujud dari perlindungan hukum terhadap Notaris itu sendiri. Oleh karena dengan adanya suatu pengawasan, maka setiap Notaris dalam berperilaku dan tindakannya baik dalam menjalankan jabatannya maupun di luar jabatannya selalu dalam koridor hukum. Dengan adanya Majelis Pengawas Notaris maka akan memberikan perlindungan hukum terhadap Notaris, sehingga menghindari adanya campur tangan pihak lain berkaitan dengan Notaris dalam menjalankan jabatannya secara profesional.

Majelis Pengawas Notaris sebagai instansi yang berwenang melakukan pengawasan, pemeriksaan, dan menjatuhkan sanksi terhadap Notaris. Majelis Pengawas Notaris memiliki jenjang yaitu Majelis Pengawas Daerah, Majelis Pengawas Wilayah dan Majelis Pengawas Pusat. Setiap Majelis Pengawas mempunyai wewenang masing-masing, wewenang MPD diatur dalam UUJN, Peraturan Menteri Hukum dan Hak Asasi Manusia Republik Indonesia Nomor M.02.PR.08.10 Tahun 2004 tentang Tata Cara Pengangkatan Anggota, Pemberhentian Anggota, Susunan Organisasi, Tata Kerja, dan Tata Cara Pemeriksaan Majelis Pengawas, dan Keputusan Menteri Hukum dan Hak Asasi Manusia Republik Indonesia Nomor M.39-PW.07.10. Tahun 2004 tentang Sekretariat Majelis Pengawas Notaris. Berikut adalah kewenangan-kewenangan yang dimiliki oleh MPD:

Berdasarkan ketentuan Pasal 70 UUJN, Majelis Pengawas Daerah berwenang:

a. menyelenggarakan sidang untuk memeriksa adanya dugaan pelanggaran Kode Etik Notaris atau pelanggaran pelaksanaan jabatan Notaris;

${ }^{21}$ Suparman Marzuki, Etika dan Kode Etik Profesi Hukum, Cetakan Pertama, FH UII Press, Yogyakarta, 2017, hlm. 6 . 
b. melakukan pemeriksaan terhadap Protokol Notaris secara berkala 1 (satu) kali dalam 1 (satu) tahun atau setiap waktu yang dianggap perlu;

c. memberikan izin cuti untuk waktu sampai dengan 6 (enam) bulan;

d. menetapkan Notaris Pengganti dengan memperhatikan usul Notaris yang bersangkutan;

e. menentukan tempat penyimpanan Protokol Notaris yang pada saat serah terima Protokol Notaris telah berumur 25 (dua puluh lima) tahun atau lebih;

f. menunjuk Notaris yang akan bertindak sebagai pemegang sementara Protokol Notaris yang diangkat sebagai pejabat negara sebagaimana dimaksud dalam Pasal 11 ayat (4);

g. menerima laporan dari masyarakat mengenai adanya dugaan pelanggaran Kode Etik Notaris atau pelanggaran ketentuan dalam undang-undang ini; dan

h. membuat dan menyampaikan laporan sebagaimana dimaksud pada huruf a, huruf $b$, huruf c, huruf d, huruf e, huruf $f$, dan huruf g kepada Majelis Pengawas Wilayah.

Berdasarkan Pasal 13 ayat (2) Permenkumham RI Nomor M.02.PR.08.10 Tahun 2004, Majelis Pengawas Daerah berwenang:

a. memberikan izin cuti untuk jangka waktu sampai dengan 6 (enam) bulan;

b. menetapkan Notaris Pengganti;

c. menentukan tempat penyimpanan protokol Notaris yang pada saat serah terima protokol Notaris telah berumur 25 (dua puluh lima) tahun atau lebih;

d. menerima laporan dari masyarakat mengenai adanya dugaan pelanggaran Kode Etik Notaris atau pelanggaran ketentuan dalam undang-undang;

e. memberi paraf dan menandatangani daftar akta, daftar surat di bawah tangan yang disahkan, daftar surat di bawah tangan yang dibukukan, dan daftar surat lain yang diwajibkan undang-undang;

f. menerima penyampaian secara tertulis salinan dari daftar akta, daftar surat di bawah tangan yang disahkan, dan daftar surat di bawah tangan yang dibukukan yang telah disahkannya, yang dibuat pada bulan sebelumnya paling lambat 15 (lima belas) hari kalender pada bulan berikutnya, yang memuat sekurangkurangnya nomor, tanggal, dan judul akta.

Seperti halnya Majelis Pengawas Notaris, Dewan Kehormatan Notaris juga memiliki jenjang yang meliputi Dewan Kehormatan Daerah, Dewan Kehormatan Wilayah, dan Dewan Kehormatan Pusat. Pengertian dan tugas Dewan Kehormatan menurut Pasal 1 ayat (8) huruf a Kode Etik Notaris adalah alat perlengkapan perkumpulan sebagai suatu badan atau lembaga yang mandiri dan bebas dari keberpihakan dalam perkumpulan yang bertugas untuk: (a) melakukan pembinaan, bimbingan, pengawasan, pembenahan dalam menjunjung tinggi kode etik; (b) memeriksa dan mengambil keputusan atas dugaan pelanggaran ketentuan kode etik yang bersifat internal atau yang tidak mempunyai kaitan dengan kepentingan masyarakat secara langsung; (c) memberikan saran dan pendapat kepada Majelis Pengawas atas dugaan pelanggaran kode etik dan jabatan Notaris. 
Pengertian Dewan Kehormatan Wilayah menurut Pasal 1 ayat (8) huruf c Kode Etik Notaris adalah Dewan Kehormatan pada tingkat wilayah yaitu pada tingkat provinsi atau yang setingkat dengan itu yang bertugas untuk melakukan pembinaan, bimbingan, pengawasan pembenahan anggota dalam menjunjung tinggi kode etik serta memeriksa dan mengambil keputusan atas dugaan pelanggaran ketentuan kode etik dan/atau disiplin organisasi, yang bersifat internal atau yang tidak mempunyai kaitan dengan kepentingan masyarakat secara langsung pada tingkat banding dan dalam keadaan tertentu pada tingkat pertama dan memberikan saran dan pendapat kepada Majelis Pengawas Wilayah dan/atau Majelis Pengawas Daerah atas dugaan pelanggaran Kode Etik dan Jabatan Notaris.

Pengertian Dewan Kehormatan Pusat menurut Pasal 8 ayat (1) huruf b Kode Etik Notaris adalah Dewan Kehormatan pada tingkat nasional dan yang bertugas untuk melakukan pembinaan, bimbingan, pengawasan, pembenahan anggota, dalam menjunjung tinggi kode etik, memeriksa dan mengambil keputusan atas dugaan pelanggaran ketentuan kode etik dan/atau disiplin organisasi yang bersifat internal atau yang tidak mempunyai kaitan dengan kepentingan masyarakat, secara langsung, pada tingkat akhir dan bersifat final, memberikan saran dan pendapat kepada Majelis Pengawas atas dugaan pelanggaran kode etik dan jabatan Notaris.

Apabila mencermati pengertian di atas, ditemukan tumpang tindih kewenangan antara Majelis Pengawas Daerah (MPD) dengan Dewan Kehormatan Notaris. Berdasarkan ketentuan Pasal 70 huruf g UUJN dan Pasal 13 ayat (2) huruf d Permenkumham RI Nomor M.02.PR.08.10 Tahun 2004 diatur bahwa MPD memiliki wewenang untuk menerima laporan adanya dugaan pelanggaran kode etik oleh Notaris. MPD mempunyai kewenangan untuk melaksanakan pengawasan menurut UUJN. Dewan Kehormatan Notaris mempunyai kewenangan untuk melaksanakan ketentuan menurut kode etik jabatan Notaris. Hal ini sesuai dengan isi Pasal 83 ayat (1) UUJN, bahwa organisasi Notaris (INI) menetapkan dan menegakkan Kode Etik Notaris.

Rio Kustianto Wironegoro pada saat wawancara menyatakan bahwa yang dilakukan oleh Majelis Pengawas Notaris dan Dewan Kehormatan Notaris itu tidak ada bedanya. Namun pengawasan Majelis Pengawas Notaris itu lebih luas karena mengawasi pelaksanaan tugas jabatan Notaris agar sesuai dengan ketentuan UUJN dan juga kode etik Notaris. Disamping itu Majelis Pengawas Notaris itu organisasi bentukan pemerintah sedangkan Dewan Kehormatan Notaris hanya bentukan organisasi. Meskipun Majelis Pengawas Notaris mengawasi dua ketentuan UUJN dan Kode Etik tetapi yang paling dominan itu mengawasi jabatan Notaris yang bersangkutan dengan UUJN.

Rio Kustianto Wironegoro juga menjelaskan lebih lanjut mengenai perbedaan antara Majelis Pengawas Notaris dan Dewan Kehormatan Notaris. 
Perbedaannya hanyalah sanksi yang diberikannya kepada Notaris yang melanggar kode etik maupun kewenangan jabatanya. Sanksi paling berat yang dapat diterapkan Majelis Pengawas Notaris adalah pemberhentian menjadi Notaris secara tetap, sedangkan sanksi paling berat yang dapat dijatuhkan Dewan Kehormatan Notaris itu hanya dikeluarkan dari anggota perkumpulan Notaris. ${ }^{22}$

Dyah Budi Mumpuni juga memberikan penjelasan bahwa yang dilakukan Majelis Pengawas Notaris dan Dewan Kehormatan Notaris itu tidak ada bedanya sama sekali. Hanya saja pengawasan yang dilakukan Majelis Pengawas Notaris itu bersifat pasif menunggu laporan dari masyarakat jika diduga adanya pelanggaran jabatan Notaris karena tidak mungkin Majelis Pengawas Notaris itu melakukan pengawasan satu persatu setiap Notaris. Sedangkan pengawasan Dewan Kehormatan Notaris bersifat aktif yang artinya Dewan Kehormatan itu dapat melakukan pengawasan atas inisiatif sendiri tanpa menunggu adanya laporan dari masyarakat.

Hal di atas berdasarkan Pasal 9 ayat (1) Kode Etik Notaris yang berbunyi, apabila ada anggota yang diduga melakukan pelanggaran terhadap kode etik, baik dugaan tersebut berasal dari pengetahuan Dewan Kehormatan Daerah sendiri maupun karena laporan dari Pengurus Daerah sendiri maupun karena laporan dari Pengurus Daerah ataupun pihak lain kepada Dewan Kehormatan Daerah, maka selambat-lambatnya dalam waktu tujuh (7) hari kerja Dewan Kehormatan Daerah untuk membicarakan dugaan terhadap pelanggaran tersebut. Contoh yang bisa diamati adalah jika ada seorang Notaris melakukan promosi ataupun iklan di media sosial dan diketahui sendiri oleh salah satu anggota anggota Dewan Kehormatan Notaris maka Notaris tersebut dapat diberikan sanksi tanpa menunggu laporan dari masyarakat. ${ }^{23}$

Notaris Nurhadi Darussalam juga memberikan penjelasan bahwa sebenarnya tidak ada perbedaan sama sekali pengawasan preventif yang dilakukan Majelis Pengawas Notaris dengan Dewan Kehormatan Notaris untuk mencegah terjadinya pelanggaran kode etik yang dilakukan oleh Notaris. Notaris Nurhadi Darussalam menjelaskan bahwa sebetulnya tidak ada tumpang tindih antara Dewan Kehormatan Notaris (DKN) dengan Majelis Pengawas Notaris (MPN) terkait pelaksanaan pengawasan dan pembinaan Notaris hingga pelaporan apabila terjadi pelanggaran jabatan maupun Kode Etik Notaris.

MPN itu mengawasi kinerja Notaris berdasarkan UUJN dan perilaku Notaris berdasarkan kode etik. MPN juga mengawasi yang berhubungan dengan eksternal organisasi yang dampaknya tidak dengan sesama Notaris namun

${ }^{22}$ Hasil wawancara dengan Rio Kustianto Wironegoro, Op. Cit.

${ }^{23}$ Hasil wawancara dengan Dyah Maryuliani Budi Mumpuni, Op. Cit. 
dampaknya ke masyarakat. Contohnya Notaris membeda-bedakan klien, sementara DKN mempunyai kewenangan untuk menegakkan kode etik secara konkrit dalam mengawasi perilaku Notaris sehari-hari. DKN mengawasi yang berhubungan dengan internal organisasi yang berhubungan dengan sesama Notaris, misalnya Notaris a menjelek-jelekan Notaris b otomatis Notaris yang dijelekan tersebut telah dirugikan. ${ }^{24}$

Kemudian terkait dengan pelaporan yang dilakukan oleh masyarakat, belum jelas mengenai perbedaan antara laporan yang ditujukan ke Majelis Pengawas Notaris dengan Dewan Kehormatan Notaris. Apabila mengacu pada ketentuan Pasal 1 angka 3 Peraturan Menteri Hukum dan Hak Asasi Manusia Republik Indonesia Nomor 15 Tahun 2020 tentang Tata Cara Pemeriksaan Majelis Pengawas Terhadap Notaris yang mengatur bahwa, laporan adalah pengaduan masyarakat sebagai pihak yang dirugikan akibat perilaku dan/atau pelaksanaan jabatan Notaris, serta laporan yang berasal dari pelaksanaan kewenangan Majelis Pengawas.

Rio Kustianto Wironegoro mengatakan bahwa jika ada masyarakat yang melaporkan pelanggaran kode etik maka bisa ke Majelis Pengawas Notaris maupun Dewan Kehormatan Notaris. Majelis Pengawas Notaris hanya sebatas menerima laporan saja mengenai pembinaan dan sanksi ditujukan kepada organisasi yang bersangkutan. Pada dasarnya Majelis Pengawas Notaris tidak boleh menolak laporan yang ditujukan kepadanya meskipun laporan tersebut menyangkut pelanggaran kode etik. Hal tersebut seperti yang diamanatkan di dalam Peraturan Menteri Hukum dan Hak Asasi Manusia No.M.02.PR.08.10 Tahun 2004 Pasal 13 ayat 4, bahwa Majelis Pengawas Daerah bertugas menerima laporan dari masyarakat mengenai adanya dugaan pelanggaran Kode Etik Notaris atau pelanggaran ketentuan dalam undang-undang.

Dyah Maryulina Budi Mumpuni dan Nurhadi Darussalam bahwa jika ada pelaporan dari masyarakat yang menyangkut kode etik maka dapat ditunjukan kepada Majelis Pengawas Notaris atau Dewan Kehormatan Notaris. Namun apabila jika ditunjukan kepada Majelis Pengawas Notaris yang pelanggarannya itu berhubungan dengan pelanggaran kode etik Notaris, misalnya pelanggaran Notaris memasang promosi di media sosial dan laporan itu ditunjukan kepada Majelis Pengawas Notaris maka Majelis Pengawas Notaris meneruskan laporannya tersebut ke Dewan Kehormatan Notaris. Jika pelaporan tersebut berkaitan dengan larangan dan kewenangan jabatan Notaris, misalnya Notaris tidak merahasiakan akta klien maka yang berwenang melakukan pemeriksaan dan pembinaan adalah Majelis Pengawas Notaris.

${ }^{24}$ Hasil wawancara dengan Nurhadi Darussalam, Op. Cit. 


\section{Penutup}

Berdasarkan analisis di atas, maka penelitian ini berkesimpulan bahwa, pertama, pengawasan yang dilakukan Majelis Pengawas Notaris untuk mencegah terjadinya pelanggaran jabatan Notaris dilakukan dengan cara mengadakan seminar tentang kenotariatan, mengadakan pertemuan sebulan sekali yang dihadiri Majelis Pengawas Daerah guna memberikan arahan supaya menjalankan UUJN dan Kode Etik serta Notaris dituntut untuk tetap menambah wawasan tentang kenotariatan, serta Majelis Pengawas Daerah itu melakukan kunjungan ke kantor Notaris minimal setahun sekali guna melakukan pengecekan protokol Notaris.

Pengawasan yang dapat dilakukan Majelis Pengawas Notaris untuk mencegah terjadinya pelanggaran jabatan Notaris hanyalah pengawasan yang bersifat pasif yang artinya pengawasannya hanya menunggu laporan dari masyarakat tidak mengawasi satu persatu Notaris. Notaris yang diduga atau terbukti melakukan pelanggaran jabatan baru kemudian diberikan pembinaan berupa penjatuhan sanksi, namun penjatuhan sanksi juga disesuaikan dengan berat ringannya pelanggaran. Apabila Notaris melakukan pelanggaran yang bersifat ringan maka Dewan Kehormatan Notaris atau Majelis Pengawas Notaris baru memberikan teguran dan memberikan solusi atau arahan supaya Notaris tersebut tidak melakukan pelanggaran di kemudian hari.

Kedua, bahwa antara Majelis Pengawas Notaris dan Dewan Kehormatan Notaris itu tidak ada bedanya sama sekali karena pada dasarnya pengawasan preventif itu bersifat pencegahan atau penanggulangan agar tidak terjadi pelanggaran Kode etik Notaris maupun kewenangan jabatan Notaris. Selanjutnya mengenai perbedaan laporan dari masyarakat yang ditujukan kepada Majelis Pengawas Notaris dan Dewan Kehormatan Notaris itu tidak ada bedanya sama sekali sehingga apabila masyarakat melaporkan ke salah satu organisasi tersebut bisa saja namun akan ditindaklanjuti oleh organisasi yang berwenang karena menyangkut sanksi yang akan diberikannya.

Majelis Pengawas Notaris harus lebih aktif mengadakan sosialisasisosialisasi mengenai aturan-aturan pelaksanaan tugas jabatan Notaris demi menghindari terjadinya pelanggaran yang dilakukan oleh Notaris yang dapat merugikan Notaris, perkumpulan Notaris, dan juga masyarakat yang menggunakan jasa Notaris.

Majelis Pengawas Daerah seharusnya tidak perlu diberi kewenangan untuk memeriksa adanya dugaan pelanggaran kode etik jabatan Notaris, karena organisasi jabatan Notaris secara internal sudah mempunyai institusi sendiri, jika 
ada anggotanya melanggar kode etik jabatan Notaris. MPD mempunyai kewenangan untuk melaksanakan pengawasan menurut UUJN. Dewan Kehormatan Notaris mempunyai kewenangan untuk melaksanakan ketentuan menurut kode etik jabatan Notaris. Hal ini sesuai dengan isi Pasal 83 ayat (1) UUJN, bahwa organisasi Notaris (INI) menetapkan dan menegakkan Kode Etik Notaris.

\section{Daftar Pustaka}

\section{Buku}

Budiono, Herlien, Notaris dan Kode Etiknya, Disampaikan pada Upgrading dan Refreshing Course Nasional Ikatan Notaris Indonesia, Ikatan Notaris Indonesia, Medan, 2007.

Ibrahim, Johnny, Teori dan Metodologi Penelitian Hukum Normatif, Cetakan Keempat, Banyumedia, Jakarta, 2008.

Lumban Tobing, G.H.S., Peraturan Jabatan Notaris, Erlangga, Jakarta, 1983.

Luthfan Hadi Darus, Muhammad, Hukum Notariat dan Tanggungjawab Jabatan Notaris, Cetakan Pertama, UII Press, Yogyakarta, 2017.

M. Hadjon, Philipus dan Tatiek Sri Djatmiati, Argumentasi Hukum, Gadjah Mada University Press, Yogyakarta, 2005.

Mahmud Marzuki, Peter, Penelitian Hukum, Cetakan Keduabelas, Prenadamedia Group, Jakarta, 2016.

Marzuki, Suparman, Etika dan Kode Etik Profesi Hukum, Cetakan Pertama, FH UII Press, Yogyakrta, 2017.

Subekti, R. dan R. Tjitrosudibio, Kitab Undang-Undang Hukum Perdata, PT. Pradnya Paramita, Jakarta, 2009.

\section{Peraturan Perundang-undangan}

Kitab Undang-undang Hukum Pidana.

Kitab Undang-Undang Hukum Perdata.

Undang-Undang Nomor 5 Tahun 1986 tentang Peradilan Tata Usaha Negara.

Undang-Undang Nomor 4 Tahun 1996 tentang Hak Tanggungan Atas Tanah Beserta Benda-Benda yang Berkaitan Dengan Tanah.

Undang-Undang Nomor 2 Tahun 2014 tentang Perubahan Atas Undang-Undang Nomor 30 Tahun 2004 tentang Jabatan Notaris.

Peraturan Pemerintah Republik Indonesia Nomor 24 Tahun 2016 tentang Perubahan Atas Peraturan Pemerintah Nomor 37 Tahun 1998 tentang Peraturan Jabatan Pejabat Pembuat Akta Tanah.

Peraturan Menteri Hukum dan HAM Republik Indonesia Nomor M.02.PR.08.10 Tahun 2004 tentang Tata Cara Pengangkatan Anggota, Pemberhentian Anggota, Susunan Organisasi, Tata Kerja, dan Tata Cara Pemeriksaan Majelis Pengawas. 
Keputusan Menteri Keuangan Republik Indonesia Nomor 338/KMK.01/2000 tentang Pejabat Lelang.

Kode Etik Notaris Ikatan Notaris Indonesia.

\section{Tesis dan Jurnal}

Otong Satyagraha, "Aspek Hukum Kekuatan Pembuktian Akta Otentik di Pengadilan (Studi Kasus Putusan Pengadilan Nomor: 158/Pdt.G/2015/Pn.Smn)", Tesis, Dalam https://dspace.uii.ac.id/ bitstream/handle/123456789/11386/THESIS.pdf?sequence=1\&isAllowed $=\mathrm{y}$, Akses 5 Januari 2020.

Sita Arini Umbas, "Kedudukan Akta Di Bawahtangan Yang Telah Dilegalisasi Notaris Dalam Pembuktian Di Pengadilan", Tesis, dalam https:/ / media.neliti.com/media/publications/148712-ID-kedudukanakta-di-bawah-tangan-yang-tela.pdf, Akses 5 Januari 2020.

Philipus M. Hadjon, "Tentang Wewenang Pemerintahan (Bestuursbevoegdheid)", Jurnal, Pro Justicia, Fakultas Hukum Universitas Parahyangan Bandung Tahun XVI Nomor 1, Januari 1998.

\section{Data Elektronik:}

https:/ / wetten.overheid.nl/BWBR0010388/2020-01-01, Akses 16 April 2020. 